Research Article

\title{
Experimental Analysis of the Potential Induced Degradation Effect on Organic Solar Cells
}

\author{
S. C. Akcaoğlu, ${ }^{1}$ G. Martinopoulos, ${ }^{1}$ and C. Zafer $^{2}$ \\ ${ }^{1}$ School of Science and Technology, International Hellenic University, 57001 Thermi, Thessaloniki, Greece \\ ${ }^{2}$ Solar Energy Institute, Ege University, Bornova, 35100 İzmir, Turkey \\ Correspondence should be addressed to G. Martinopoulos; g.martinopoulos@ihu.edu.gr
}

Received 11 April 2017; Revised 26 June 2017; Accepted 3 July 2017; Published 13 August 2017

Academic Editor: Nikolai V. Tkachenko

Copyright (C) 2017 S. C. Akcaoğlu et al. This is an open access article distributed under the Creative Commons Attribution License, which permits unrestricted use, distribution, and reproduction in any medium, provided the original work is properly cited.

\begin{abstract}
Renewable energy applications are increasing daily, and solar electricity, in the form of photovoltaics, is getting more and more important worldwide. As photovoltaics are connected both in series and in parallel, the panels are exposed to high potentials compared to the ground; thus, high voltage stress (HVS) occurs. The scope of this paper is to analyze experimentally the potential induced degradation (PID) in organic solar cells. To that end, organic solar cells are manufactured and are then undergone a series of voltage-dependent degradation and time-dependent voltage degradation tests. In addition to that, they are also exposed to gaseous oxygen, oxygen plasma, air degradation, and annealing, and the degradation effects are compared with PID results. From the analysis, it is apparent that annealing, air, gaseous oxygen, and oxygen plasma degradation have similar effects with PID, while due to simple diode characteristics, organic cells proved to be relatively durable to potential induced degradation. At low voltages $(10 \mathrm{~V})$, the organic cells withstood degradation adequately, with a drop of $23 \%$ in their initial efficiency. As voltage increased, the degradation rate increased considerably reaching a $93 \%$ efficiency drop when $30 \mathrm{~V}$ was applied for 20 minutes.
\end{abstract}

\section{Introduction}

In the field of power production, the use of photovoltaics has seen a tremendous increase, either for domestic use or for remote production with more than $178 \mathrm{GW}$ of installed capacity at the end of 2014 [1]. During the last years, a new generation of solar cells has emerged to cater for different consumer needs with organic cells at the forefront of research. Organic cells have the potential to provide cheap solar electricity, due to their low-cost production [2], but have still to overcome disadvantages associated with their low efficiency and stability and poor mechanical properties compared with other types of solar cells [3].

In order to achieve high installed capacities, solar panels are connected either in series or in parallel, so they are exposed to high potentials compared to the ground, and thus, high voltage stress (HVS) occurs. This exposure to an external potential causes two kinds of power degradation, reversible (polarization) and irreversible (electro corrosion). In principle, HVS results in a small amount of current leakage. PID is influenced furthermore by humidity and high temperature along with the exposure of negative voltage [4].

Usually, most solar panels provide certificates that they possess no major PID effect, after being tested. In this test, aluminum is used as a catalyzer conductor, and therefore, it is called the "aluminum foil test" [5]. PV panels are considered PID-free if they succeed to have an initial power loss of less than 5\% throughout all testing conditions. Of course in real life applications, degradation would be higher than $5 \%$ due to temperature fluctuations, humidity, dirt, and soiling of the panel's front surface. Also, as most panels are usually deployed with different inclinations compared to the ideal test conditions, they will not have the same rate of cooling achieved during test conditions and there will also 


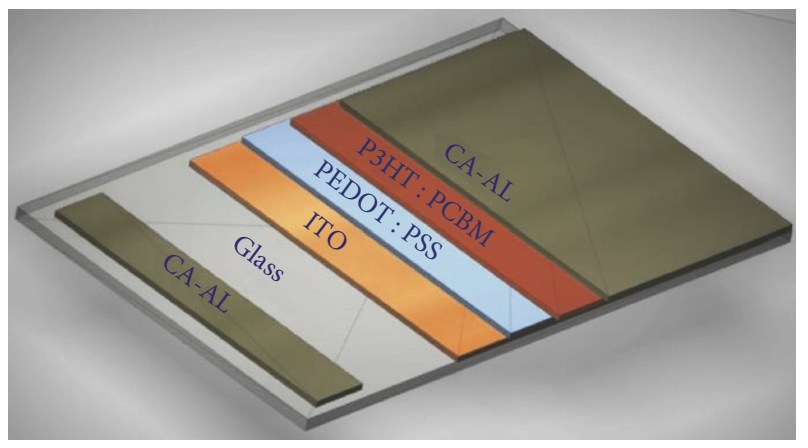

Figure 1: Organic photovoltaic cell.

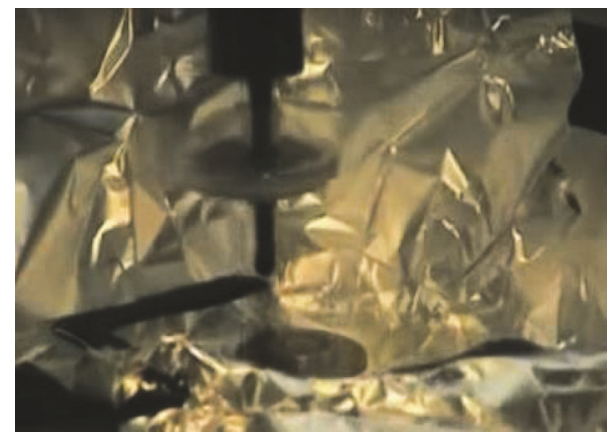

FIgURE 2: $40 \mathrm{~nm}$ PDOT: PSS coating ( $1 \mathrm{~min}$ spin coating at $3000 \mathrm{rpm})$.

be more dust and dirt accumulation onto the solar panel's surface. Temperature fluctuations, humidity, dirt, and inclination factors may increase the PID effect as much as 2 times compared to its optimal ratio. Voltage potential between the solar panel and the ground is a key feature for PID. This voltage potential depends on the number of serially interconnected panels, the amount of incident solar radiation, and panel temperature [6]. Also, the grounding scheme of the panels should be carefully designed in order to decrease voltage potential. Amplitude of the potential is directly linked to its poles' grounding type such as negative, positive, or no pole being grounded. The difference can be either positively or negatively fixed or not fixed at all [7].

PID can be limited by controlling the parameters that cause degradation, which can be categorized into four groups, namely, environmental-, system-, module-, and cell-level factors [8].

It has been proven that environmental factors such as humidity and temperature have a direct negative effect on PID, which in return results in a severe loss of power production. There are tests that determine the level of degradation that is associated with humidity and temperature. The damping heat test (DHT) and temperature cycling test (TCT) are two of them $[8,9]$.

A number of researchers have analyzed the effect of temperature and humidity, and the results indicate that temperature increases from $25^{\circ} \mathrm{C}$ to $85^{\circ} \mathrm{C}$, leading to increased degradation, while an increase in humidity from $20 \%$ to

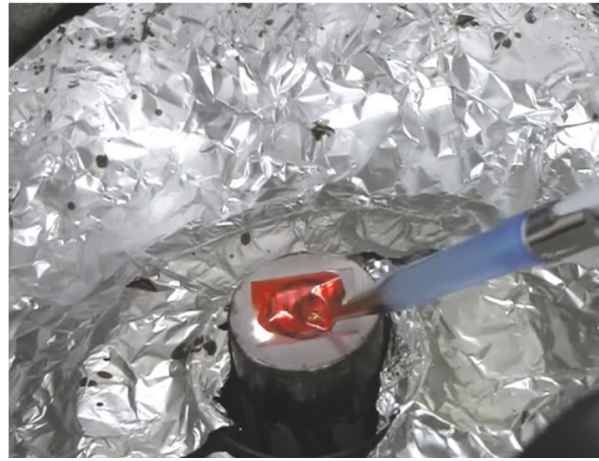

FIgURE 3: P3HT: PCBM $(1: 1)$ spin coating.

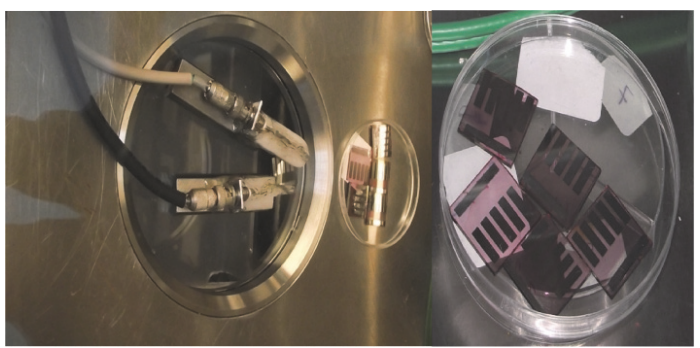

FIgURE 4: Organic cells used for testing.

$85 \%$ will cause severe potential induced degradation problems that range from $5 \%$ to as much as $95 \%$ [8].

The effect of the voltage stress on the solar module affects the PID phenomenon in terms of a system factor which is determined by comparing the generated module voltage to the ground level stress. System grounding techniques, as well as the module's position within the photovoltaic array, are major determinants of the system-level factor. Other factors affecting PID are the type of materials used within the solar modules, in the front sheet; the encapsulating material, in the back sheet; and the overall module (frame, mounting, etc.) design [7,9], which are also called as module-level factors $[8,10]$. Regarding cell-level factors, the antireflective coating, emitter depth, and type of base doping are three major parameters that also affect PID in the cell level $[9,10,11]$.

This study focuses on analyzing the PID effect on organic solar cells experimentally. The PID test is performed by applying voltage between the poles of organic solar cells in order to deter degradation. Illuminated and dark I-V characterizations are completed before and after degradation. Also, I-V characterizations of the solar cell are observed under different $\left(1-100 \mathrm{~mW} / \mathrm{cm}^{2}\right)$ light intensities. Electrochemical impedance spectrometry (EIS) and external quantum efficiencies (EQE) are measured before and after degradation in order to understand the PID effect at the electrochemical level in order to minimize its effect on the solar cells' efficiency and overall durability. In the case of 3rdgeneration solar cells, to our knowledge, this is the first study that tries to quantify the effects of PID to the characteristics of an organic cell. 


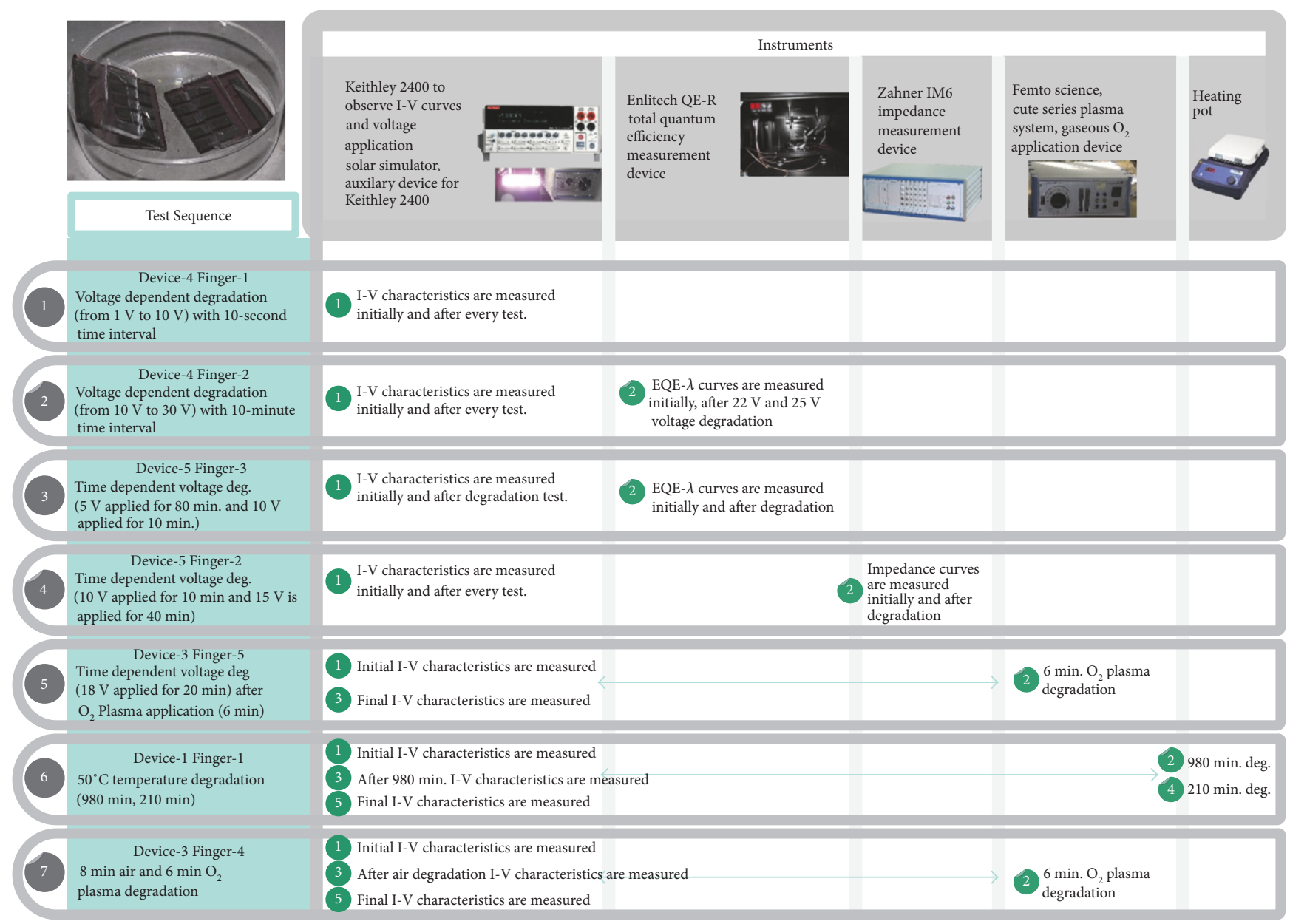

FIGURE 5: Testing procedure.

\section{Experimental Setup}

Initially, six organic solar cells were manufactured in the lab and then tested. The cells were composed of four layers; respectively, indium tin oxide (ITO), poly(3,4-ethylenedioxythiophene) : polystyrene sulfonate (PEDOT:PSS), an active layer, and $\mathrm{Ca}-\mathrm{Al}$ cathode are mounted over an ITO-coated glass substrate (from Delta Tech. Corp., $25 \times 25 \mathrm{~mm}$ in size and an $R_{\text {sheet }}$ of $\left.10 \Omega / \mathrm{sq}\right)$. The structure of the manufactured cell was ITO/PEDOT:PSS/P3HT:PCBM (1.1 ratio)/Ca/Al and is schematically presented in Figure 1.

Because of the extremely small thickness of the active layers in the organic solar cell, very thorough cleaning is needed in order to avoid short circuits or bad contacts between the layers. Electrodes were sonicated sequentially in water and acetone 2-propanol, and then, substrates were treated with oxygen plasma for $5 \mathrm{~min}$. After cleaning the ITO-covered substrates, the device fabrication began. At first, the $40 \mathrm{~nm}$ thick PEDOT:PSS (AL4083 is spin-coated at $3000 \mathrm{rpm}$ for 1 minute) as illustrated in Figure 2; after that, the device is vacuumed and heated at $120^{\circ} \mathrm{C}$ for 30 minutes at a heat flow rate of $0.83 \mathrm{~W}$ in a vacuum oven. As PEDOT:PSS is a transparent conductive polymer, it is useful to enhance the contacts between the ITO electrode and the donor acceptor (active layer).

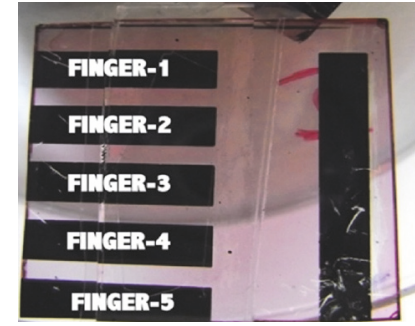

(a)



(b)
FIgURE 6: Organic cell and its fingers before (a) and after (b) the degradation process.

Subsequently, the P3HT and PCBM layers were separately dissolved in 1,2-DCB (dichlorobenzene), and then, they were mixed together at a $1: 1 \mathrm{wt} / \mathrm{wt}$ ratio of $20 \mathrm{mg} / \mathrm{ml}$ each. As illustrated in Figure 3, the first three cells (1st, $2 \mathrm{nd}$, and $3 \mathrm{rd}$ device) were spin-coated at $1500 \mathrm{rpm}$ while the last three cells (4th, 5th, and 6th device) were spincoated at $2000 \mathrm{rpm}$ in order to observe the PID effect for different layer thickness.

After this process, the cells were left to dry in a covered petri dish. Then, the dried devices were vacuumed and heated at $120^{\circ} \mathrm{C}$ for 30 minutes at a heat flow rate of $0.75 \mathrm{~W}$ 
TABLE 1: All manufactured devices and their fingers with the highest efficiency.

\begin{tabular}{rcccccccc}
\hline Light intensity & Device & Device's best performed finger & $I_{\mathrm{sc}}\left(\mathrm{mA} / \mathrm{cm}^{2}\right)$ & $V_{\mathrm{oc}}(\mathrm{mV})$ & $\mathrm{FF}$ & $V_{\mathrm{mp}}(\mathrm{mV})$ & $I_{\mathrm{mp}}\left(\mathrm{mA} / \mathrm{cm}^{2}\right)$ & $\mathrm{Efficiency}(\%)$ \\
\hline & Device 1 & Finger 1 & 8,834 & 600 & 0,533 & 420 & 6,731 & 2,827 \\
& Device 2 & Finger 2 & 2,117 & 500 & 0,372 & 320 & 1,306 \\
$100 \mathrm{~mW} / \mathrm{cm}^{2}{ }^{2}$ & Fevice 3 & Finger 5 & 9,092 & 580 & 0,529 & 420 & 6,645 \\
& Device 4 & Finger 2 & 4,557 & 520 & 0,455 & 360 & 3,000 & 1,060 \\
& Device 5 & Finger 5 & 5,502 & 580 & 0,522 & 420 & 3,966 & 1,665 \\
& Device 6 & Finger 1 & 5,612 & 560 & 0,498 & 380 & 4,116 & 1,564 \\
\hline
\end{tabular}

TABLE 2: Device 4 finger 1 voltage-dependent degradation with 10-second time intervals.

\begin{tabular}{ccccccccc}
\hline Light intensity & Experiment & $I_{\mathrm{sc}}\left(\mathrm{mA} / \mathrm{cm}^{2}\right)$ & $V_{\mathrm{oc}}(\mathrm{mV})$ & $\mathrm{FF}$ & $V_{\mathrm{mp}}(\mathrm{mV})$ & $I_{\mathrm{mp}}\left(\mathrm{mA} / \mathrm{cm}^{2}\right)$ & Efficiency $(\%)$ & Power losses $(\%)$ \\
\hline & Initial & 4,807 & 340 & 0,342 & 180 & 3,101 & 0,558 & - \\
& After 1 V 10 seconds & 4,899 & 360 & 0,372 & 220 & 2,985 & 0,657 & $-17,650$ \\
$100 \mathrm{~mW} / \mathrm{cm}^{2}{ }^{2}$ & After 3 V 10 seconds & 4,795 & 280 & 0,286 & 160 & 2,401 & 0,384 & 41,501 \\
& After 4 V 10 seconds & 4,730 & 240 & 0,278 & 120 & 2,633 & 0,316 & 17,753 \\
& After 5 V 10 seconds & 4,685 & 240 & 0,283 & 120 & 2,659 & 0,319 & $-0,987$ \\
& After 10 V 10 seconds & 4,683 & 200 & 0,308 & 100 & 2,887 & 0,289 & 9,521 \\
\hline
\end{tabular}

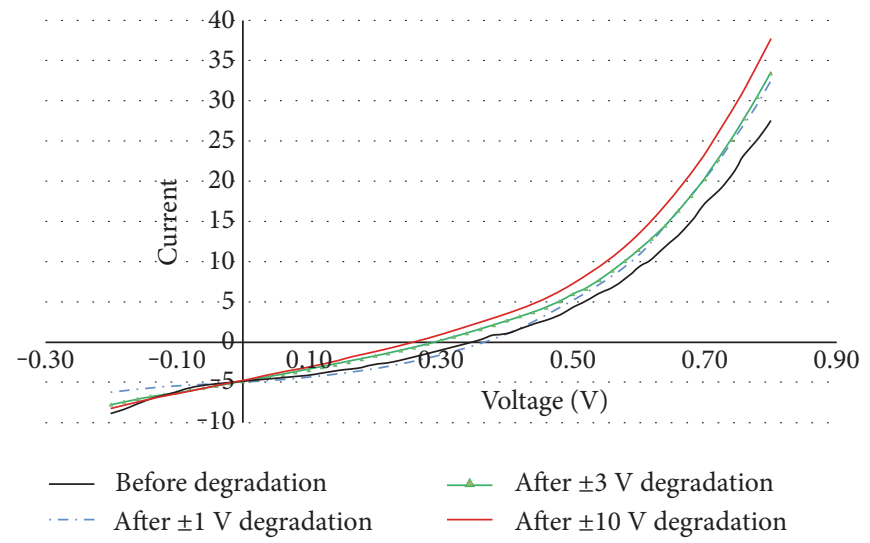

Figure 7: Device 4 finger 1 voltage-dependent degradation I-V curves.

to achieve absolute dehydration. The cathode consisted of $30 \mathrm{~nm} \mathrm{Ca}$ and $70 \mathrm{~nm} \mathrm{Al}$. As the active layer of solar cells is sensitive to atmospheric conditions (oxygen and water), the next steps were performed in a nitrogen-filled environment.

The evaporation of metals was performed at an absolute pressure of $3.10^{-4} \mathrm{~Pa}$ at a rate of $10 \mathrm{~A} \%$. After the deposition of the cathodes, the cells were annealed at $120^{\circ} \mathrm{C}$ for 10 minutes at a heat flow rate of $1.58 \mathrm{~W}$ and were cooled in a slow process in order to avoid thermal stress. The manufactured cells are presented in Figure 4.

The characterization of the fabricated devices was done under an inert atmosphere in a glove box equipped with a double-source thermal evaporator and a solar simulator (MBRAUN 200B, Germany).

The test process was divided into four phases according to the literature [12]. In the first phase, constant voltage was applied to the cell and time-dependent measurements were taken. In the second phase, various voltages $(0-30 \mathrm{~V})$ were applied in order to test voltage dependence. The third and fourth phases covered the effect of ambient conditions and temperature degradation and air $\mathrm{O}_{2}$ and plasma degradation, respectively. The testing process is illustrated in Figure 5.

Usually after applying small voltages to the cell, efficiency starts to increase due to the capacitive characteristics of the cell. Time interval and discharging techniques were used in order to prevent the charging (capacitive) effect of the cell.

Five organic devices were utilized for the degradation study and each device had five fingers (Figure 6). From the six devices manufactured, three devices were used to measure the PID degradation, while two devices were used solely for the temperature degradation study.

One device was not used due to its very low efficiency. Although the same fabrication process was followed for all the fingers, not all electrodes present the same efficiency. This 
Table 3: Device 4 finger 2 voltage-dependent degradation with a 10-minute time interval.

\begin{tabular}{|c|c|c|c|c|c|c|c|c|}
\hline Light intensity & Experiment & $I_{\mathrm{sc}}\left(\mathrm{mA} / \mathrm{cm}^{2}\right)$ & $V_{\mathrm{oc}}(\mathrm{mV})$ & $\mathrm{FF}$ & $V_{\mathrm{mp}}(\mathrm{mV})$ & $I_{\mathrm{mp}}\left(\mathrm{mA} / \mathrm{cm}^{2}\right)$ & Efficiency (\%) & Power losses (\%) \\
\hline \multirow{11}{*}{$100 \mathrm{~mW} / \mathrm{cm}^{2}$} & After manufacture & 4,557 & 520 & 0,455 & 360 & 3,000 & 1,080 & - \\
\hline & Initial & 4,813 & 520 & 0,471 & 360 & 3,280 & 1,180 & - \\
\hline & After $10 \mathrm{~V} 10 \mathrm{~min}$ & 4,242 & 560 & 0,484 & 380 & 3,020 & 1,150 & 2,812 \\
\hline & After $12 \mathrm{~V} 10 \mathrm{~min}$ & 4,189 & 560 & 0,487 & 380 & 3,000 & 1,142 & 0,662 \\
\hline & After $14 \mathrm{~V} 10 \mathrm{~min}$ & 4,075 & 560 & 0,431 & 360 & 2,736 & 0,985 & 13,600 \\
\hline & After $18 \mathrm{~V} 10 \mathrm{~min}$ & 3,874 & 560 & 0,407 & 340 & 2,602 & 0,884 & 10,181 \\
\hline & After $20 \mathrm{~V} 10 \mathrm{~min}$ & 3,792 & 560 & 0,373 & 320 & 2,470 & 0,792 & 10,657 \\
\hline & After $21 \mathrm{~V} 10 \mathrm{~min}$ & 3,401 & 560 & 0,287 & 280 & 1,959 & 0,548 & 30,602 \\
\hline & After $22 \mathrm{~V} 10 \mathrm{~min}$ & 2,152 & 540 & 0,256 & 280 & 1,063 & 0,297 & 45,738 \\
\hline & After $25 \mathrm{~V} 10 \mathrm{~min}$ & 0,836 & 540 & 0,245 & 300 & 0,370 & 0,111 & 62,707 \\
\hline & After $30 \mathrm{~V} 20 \mathrm{~min}$ & 0,274 & 740 & 0,392 & 520 & 0,153 & 0,079 & 28,324 \\
\hline
\end{tabular}

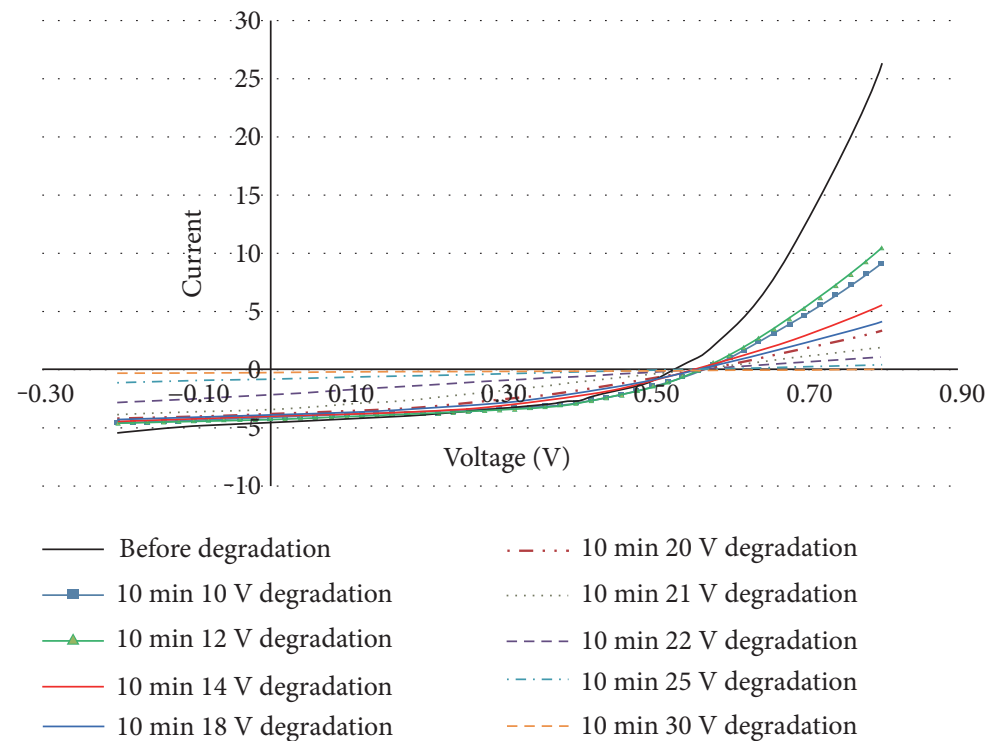

FIgURE 8: Device 4 finger 2 voltage-dependent degradation I-V curves.

is attributed to small deviations during the fabrication process, like $\mathrm{Al} / \mathrm{Ca}$ rates having small differences or small variations during the evaporation process (which is done in the glovebox). An initial characteristic of each device's most efficient finger is given in Table 1.

\section{Results}

The first test run was the $10 \mathrm{~V}$ voltage-dependent test. Voltages ranging from 1 to $10 \mathrm{~V}$ were applied for 1 to $10 \mathrm{sec}$ onds in order to verify the cell's durability (device 4 finger 1). After the $1 \mathrm{~V}$ application, all parameters except $I_{\max }\left(I_{\mathrm{mp}}\right)$ were increased and that resulted in a $17,6 \%$ increase of output. The results of the first test are given in Table 2 in a tabulated form.

As illustrated in Figure 7, due to PID, the device is losing its diode characteristics, as its I-V curves approach the $y$-axis.

Device 4 finger 2 was used for the second voltagedependent degradation test in which the applied voltage

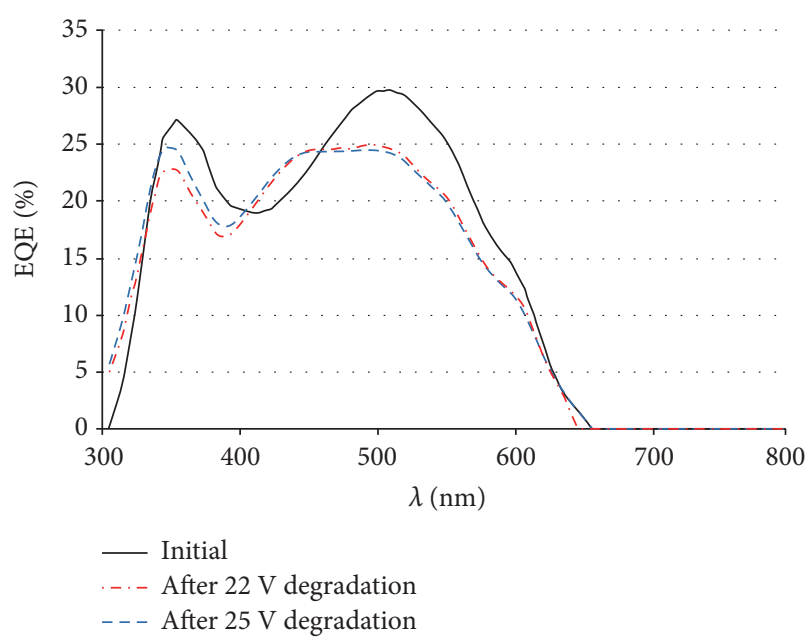

FIgURE 9: Device 4 finger 2 voltage-dependent degradation EQE- $\lambda$ curve. 
TABLE 4: Device 5 finger 3 time-dependent voltage degradation.

\begin{tabular}{ccccccccc}
\hline Light intensity & Experiment & $I_{\mathrm{sc}}\left(\mathrm{mA} / \mathrm{cm}^{2}\right)$ & $V_{\mathrm{oc}}(\mathrm{mV})$ & $\mathrm{FF}$ & $V_{\mathrm{mp}}(\mathrm{mV})$ & $I_{\mathrm{mp}}\left(\mathrm{mA} / \mathrm{cm}^{2}\right)$ & Efficiency $(\%)$ & Power losses $(\%)$ \\
\hline & Initial & 4,993 & 560 & 0,492 & 400 & 3,440 & 1,376 & - \\
& After 5 V 5 min & 5,952 & 560 & 0,485 & 380 & 4,256 & 1,617 & - \\
& After 5 V 10 min & 5,933 & 540 & 0,487 & 380 & 4,108 & 1,561 & 3,477 \\
\multirow{3}{*}{$100 \mathrm{~mW} / \mathrm{cm}^{2}$} & After 5 V 30 min & 5,807 & 540 & 0,474 & 360 & 4,134 & 1,488 & 4,664 \\
& After 5 V 80 min & 5,699 & 540 & 0,459 & 360 & 3,927 & 1,414 & 5,007 \\
& After 10 V 5 min & 5,654 & 520 & 0,470 & 360 & 3,838 & 1,381 & 2,266 \\
& After 10 V 10 min & 5,572 & 520 & 0,422 & 320 & 3,821 & 1,223 & 11,505 \\
\hline
\end{tabular}

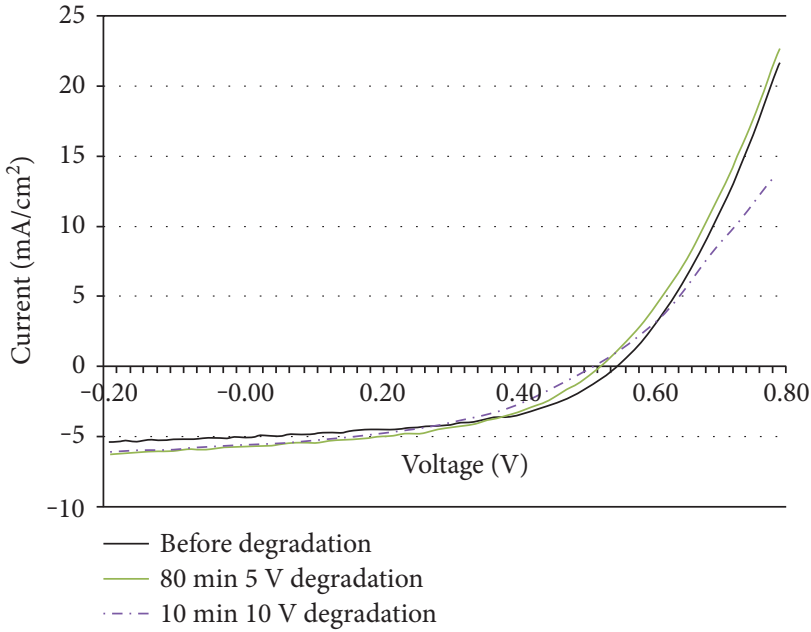

Figure 10: Device 5 finger 3 time-dependent voltage degradation I-V curves.

ranged from $10 \mathrm{~V}$ to $30 \mathrm{~V}$ with 10 -minute intervals. During this test, external quantum efficiencies were observed before degradation as well as after $22 \mathrm{~V}$ and $25 \mathrm{~V}$ were applied. Dark I-V characteristics were observed prior to the degradation and also after the $22 \mathrm{~V}$ voltage degradation test. The results of the second test are given in a tabulated form in Table 3.

From the second voltage-dependent degradation test, the highest degradation was after the $25 \mathrm{~V}$ voltage application for 10 minutes. The device lost $62 \%$ of its power generation capacity and $I_{\mathrm{mp}}$ dropped from $1,063 \mathrm{~mA} / \mathrm{cm}^{2}$ to $0,370 \mathrm{~mA} /$ $\mathrm{cm}^{2}$ while the short-circuit current fell to $0,836 \mathrm{~mA} / \mathrm{cm}^{2}$ from $2,152 \mathrm{~mA} / \mathrm{cm}^{2}$. Total efficiency also dropped to $0,079 \%$ from $1,18 \%$ corresponding to a $93,3 \%$ degradation.

As it is apparent from Figure 8, degradation effects cause the flattening of the $\mathrm{I}-\mathrm{V}$ characteristics because of the impairment of the diode features.

As illustrated in Figure 9, PID causes the external quantum efficiency to decrease. There are two peaks: one at $349 \mathrm{~nm}$ and the second one at around $500 \mathrm{~nm}$ wavelength. Before the degradation, the second peak quantum efficiency was $36,08 \%$ at a wavelength of $510 \mathrm{~nm}$, and after the $25 \mathrm{~V}$ voltage degradation, peak external quantum efficiency fell to $24,39 \%$ at a wavelength of $470 \mathrm{~nm}$.

Three different tests were done for the time-dependent voltage degradation test. Device 5 finger 3 was degraded by



FIgure 11: Device 5 finger 3 time-dependent voltage degradation EQE- $\lambda$ curve.

applying a constant $5 \mathrm{~V}$ for 80 minutes and $10 \mathrm{~V}$ voltage for 10 minutes. Device 5 finger 2 was degraded with the application of $10 \mathrm{~V}$ and $15 \mathrm{~V}$ external voltage. Finally, device 3 finger 5 was degraded by applying $18 \mathrm{~V}$ for 20 minutes. After every degradation step, there was a 3- to 5-minute waiting period to enable the device to cool down. The external quantum efficiencies were observed before and after the 10 -minute $10 \mathrm{~V}$ voltage degradation.

Power losses were observed after every voltage application. Subsequent to the 80 -minute $5 \mathrm{~V}$ voltage degradation, the device lost $13 \%$ of its power generation capacity. After that, the device was further degraded with $10 \mathrm{~V}$ for 5 minutes and this time it lost $2,26 \%$ of its output power. In addition to that, a further $11,5 \%$ power loss is observed at the end of the test (Table 4).

As illustrated in Figure 10 after the 80 -minute $5 \mathrm{~V}$ voltage degradation, the $\mathrm{I}-\mathrm{V}$ characteristics did not change much, while on the other hand, after the $10 \mathrm{~V}$ degradation for 10 minutes, the I-V curves moved towards the $x$-axis.

In Figure 11, it is apparent that the external quantum efficiency's second peak value has fallen to $29 \%$ from $34 \%$ after the last degradation (10-minute $10 \mathrm{~V}$ voltage degradation). As for the first peak value, there is an $8 \%$ decrease between the initial and postdegradation value. Also after degradation, the EQE- $\lambda$ curve has moved to the right, which means that peak external efficiency values occur at longer wavelengths compared to the initial measurements. 
TABle 5: Device 5 finger 2 time-dependent voltage degradation.

\begin{tabular}{|c|c|c|c|c|c|c|c|c|}
\hline $\begin{array}{l}\text { Light intensity } \\
\left(\mathrm{mW} / \mathrm{cm}^{2}\right)\end{array}$ & Experiment & $I_{\mathrm{sc}}\left(\mathrm{mA} / \mathrm{cm}^{2}\right)$ & $V_{\mathrm{oc}}(\mathrm{mV})$ & $\mathrm{FF}$ & $V_{\mathrm{mp}}(\mathrm{mV})$ & $I_{\mathrm{mp}}\left(\mathrm{mA} / \mathrm{cm}^{2}\right)$ & Efficiency (\%) & Power losses (\%) \\
\hline \multirow{8}{*}{100} & After manufacture & 5,047 & 580 & 0,519 & 420 & 3,620 & 1,520 & - \\
\hline & Initial & 5,792 & 560 & 0,496 & 400 & 4,120 & 1,648 & - \\
\hline & After $10 \mathrm{~V} 2 \mathrm{~min}$ & 5,767 & 520 & 0,391 & 340 & 3,445 & 1,171 & 28,926 \\
\hline & After $10 \mathrm{~V} 3 \mathrm{~min}$ & 5,826 & 520 & 0,381 & 320 & 3,611 & 1,155 & 1,347 \\
\hline & After $10 \mathrm{~V} 10 \mathrm{~min}$ & 5,686 & 490 & 0,380 & 300 & 3,533 & 1,060 & 8,278 \\
\hline & After $15 \mathrm{~V} 20 \mathrm{~min}$ & 3,687 & 480 & 0,378 & 300 & 3,436 & 1,031 & 2,731 \\
\hline & After 15 V $30 \mathrm{~min}$ & 5,522 & 480 & 0,364 & 300 & 3,218 & 0,966 & 6,355 \\
\hline & After $15 \mathrm{~V} 40 \mathrm{~min}$ & 5,519 & 470 & 0,357 & 290 & 3,201 & 0,928 & 3,844 \\
\hline 50 & \multirow{4}{*}{ After voltage degradation } & 3,344 & 400 & 0,326 & 240 & 1,817 & 0,872 & \multirow{4}{*}{-} \\
\hline 30 & & 2,236 & 340 & 0,307 & 200 & 1,166 & 0,777 & \\
\hline 10 & & 1,746 & 300 & 0,297 & 160 & 0,973 & 1,557 & \\
\hline 1 & & 0,822 & 180 & 0,278 & 100 & 0,412 & 4,123 & \\
\hline
\end{tabular}

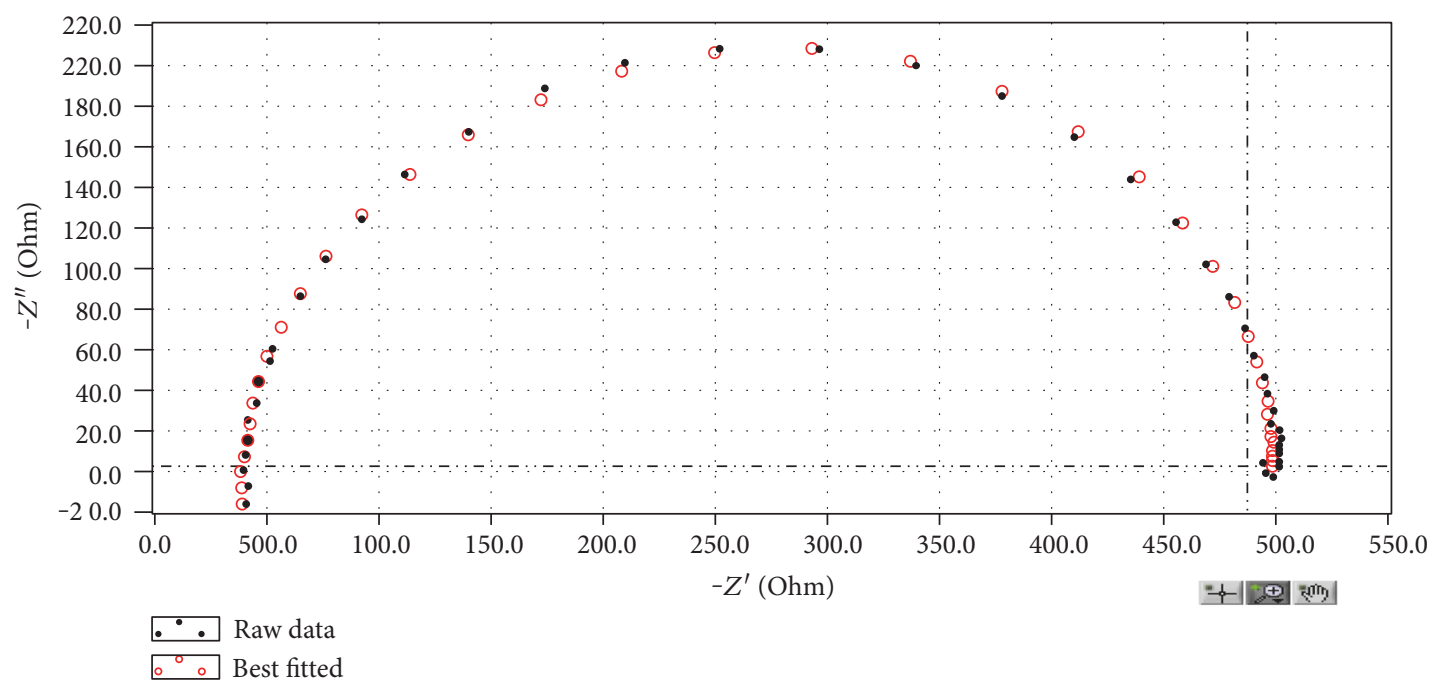

(a)

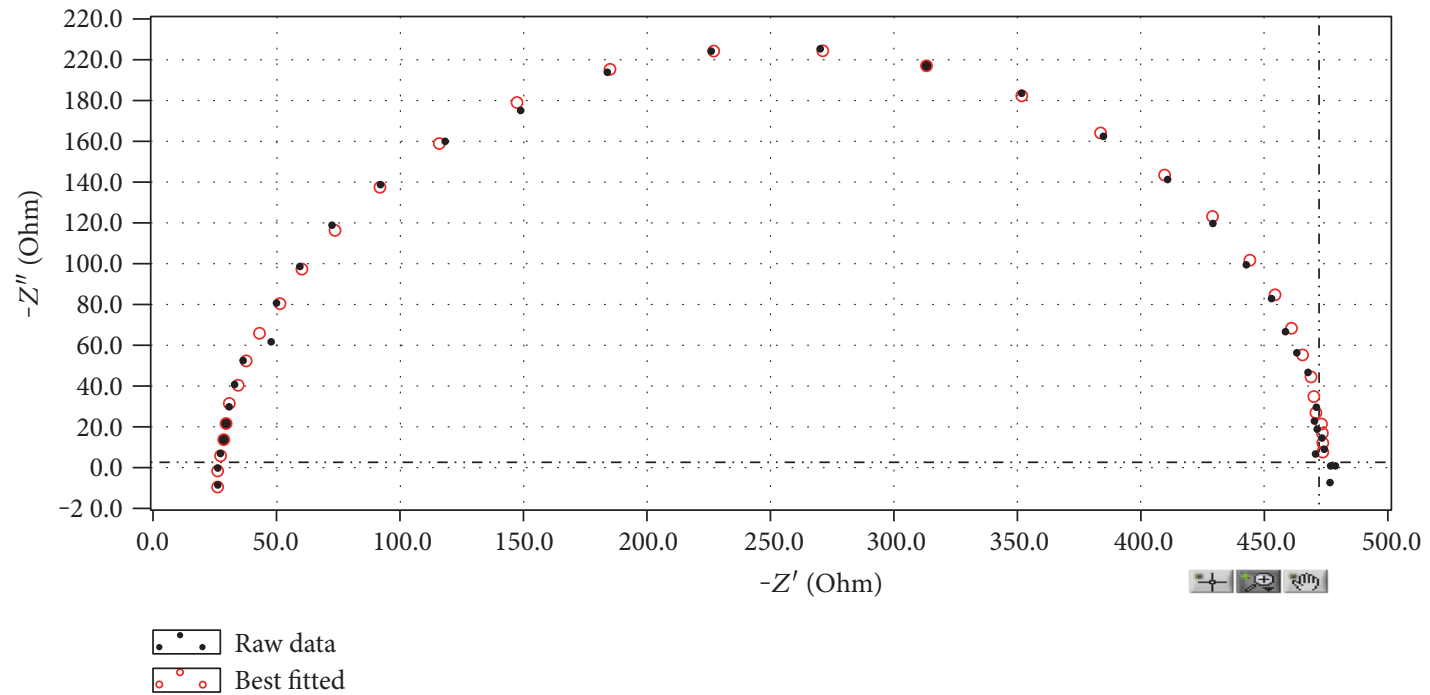

(b)

FIGURE 12: Device 5 finger 2 time-dependent voltage degradation test impedance before (a) and after (b) degradation. 
TABLE 6: Device 3 finger 5 time-dependent voltage degradation after $\mathrm{O}_{2}$ plasma application.

\begin{tabular}{ccccccccc}
\hline Light intensity & Experiment & $I_{\mathrm{sc}}\left(\mathrm{mA} / \mathrm{cm}^{2}\right)$ & $V_{\mathrm{oc}}(\mathrm{mV})$ & $\mathrm{FF}$ & $V_{\mathrm{mp}}(\mathrm{mV})$ & $I_{\mathrm{mp}}\left(\mathrm{mA} / \mathrm{cm}^{2}\right)$ & Efficiency $(\%)$ & Power losses $(\%)$ \\
\hline \multirow{3}{*}{$100 \mathrm{~mW} / \mathrm{cm}^{2}$} & Initial & 9,092 & 580 & 0,529 & 420 & 6,645 & 2,791 & - \\
& $6 \mathrm{~min} \mathrm{O}$ 2 plasma & 6,840 & 560 & 0,481 & 380 & 4,846 & 1,841 & 34,025 \\
& $18 \mathrm{~V} \mathrm{20} \mathrm{min}$ & 0,525 & 40 & 0,259 & 20 & 0,272 & 0,005 & 99,705 \\
\hline
\end{tabular}

TABle 7: Device 1 finger $150^{\circ} \mathrm{C}$ temperature degradation.

\begin{tabular}{lcccccccc}
\hline Light intensity & Experiment & $I_{\mathrm{sc}}\left(\mathrm{mA} / \mathrm{cm}^{2}\right)$ & $V_{\mathrm{oc}}(\mathrm{mV})$ & $\mathrm{FF}$ & $V_{\mathrm{mp}}(\mathrm{mV})$ & $I_{\mathrm{mp}}\left(\mathrm{mA} / \mathrm{cm}^{2}\right)$ & Efficiency $(\%)$ & Power losses $(\%)$ \\
\hline \multirow{3}{*}{$100 \mathrm{~mW} / \mathrm{cm}^{2}$} & Initial & 8,834 & 600 & 0,533 & 420 & 6,731 & 2,827 & - \\
& $980 \min 50^{\circ} \mathrm{C}$ & 4,813 & 520 & 0,472 & 360 & 3,280 & 1,181 & 58,232 \\
& $210 \mathrm{~min} 50^{\circ} \mathrm{C}$ & 4,506 & 540 & 0,442 & 340 & 3,160 & 1,074 & 9,022 \\
\hline
\end{tabular}

TABle 8: Device 3 finger 4 air and $\mathrm{O}_{2}$ plasma degradation.

\begin{tabular}{ccccccccc}
\hline Light intensity & Experiment & $I_{\mathrm{sc}}\left(\mathrm{mA} / \mathrm{cm}^{2}\right)$ & $V_{\mathrm{oc}}(\mathrm{mV})$ & $\mathrm{FF}$ & $V_{\mathrm{mp}}(\mathrm{mV})$ & $I_{\mathrm{mp}}\left(\mathrm{mA} / \mathrm{cm}^{2}\right)$ & Efficiency (\%) & Power losses (\%) \\
\hline \multirow{3}{*}{$100 \mathrm{~mW} / \mathrm{cm}^{2}$} & Initial & 8,418 & 580 & 0,536 & 420 & 6,227 & 2,615 & - \\
& 8 min air & 7,636 & 580 & 0,512 & 400 & 5,671 & 2,268 & 13,264 \\
& $6 \mathrm{~min} \mathrm{O}_{2}$ plasma & 7,364 & 560 & 0,526 & 400 & 5,425 & 2,170 & 4,343 \\
\hline
\end{tabular}

For the second time-dependent voltage degradation test, device 5 finger 2 was used. At first, $10 \mathrm{~V}$ was applied to the device for 10 minutes, and after that, the applied voltage increased to $15 \mathrm{~V}$ and was applied for a further 40-minute period.

After the degradation, light intensity was reduced from $100 \mathrm{~mW} / \mathrm{cm}^{2}$ to $1 \mathrm{~mW} / \mathrm{cm}^{2}$ in order to observe the cells' efficiency at different illuminations. Furthermore, the cell's impedance characteristics were also observed before and after degradation.

The degradation led to a reduction of efficiency which fell to $0,93 \%$ after the 40 -minute $15 \mathrm{~V}$ degradation. The highest power degradation occurred after applying $10 \mathrm{~V}$ for 2 minutes, which resulted in a $28,9 \%$ decrease in the maximum output power, as presented in Table 5.

Although total efficiency dropped to $0,93 \%$ from $1,52 \%$, changes in impedance values were limited. As illustrated in Figure 12 after degradation, series resistance has decreased; therefore, the impedance curve approached the initial one. On the other hand, changes in parallel resistance were quite limited and almost no changes were observed in the imaginary axis.

Device 3 finger 5 was used for the third time-dependent voltage degradation test. In this case, the device was initially exposed to $\mathrm{O}_{2}$ plasma for 6 minutes, and after that, $18 \mathrm{~V}$ was applied for 20 minutes. As evidenced from the results presented in Table 6, after the exposure, all parameters decreased. Efficiency dropped to $1,84 \%$ from 2,79\%; opencircuit voltage dropped to $20 \mathrm{mV}$ while a steady decrease was also observed at $I_{\mathrm{mp}}$ and short-circuit currents. The PID was very fast after the exposure as the device lost $99 \%$ of its maximum power generation capacity.

In order to test the effects of temperature, air, and $\mathrm{O}_{2}$ plasma degradation, two devices were used. To that end, device 1 finger 1 was heated to $50^{\circ} \mathrm{C}$, while for the air and $\mathrm{O}_{2}$ plasma degradation, device 3 finger 4 was used.

The results for the temperature degradation are provided in Table 7 . After $980 \mathrm{~min}$ at $50^{\circ} \mathrm{C}$ (at a $2.5 \mathrm{~W}$ heat flow rate), a power loss was about $58 \%$, while after a subsequent $210 \mathrm{~min}$ period (for a total of 1190 minutes of annealing), a power loss of another $9 \%$ occurred. By comparing post and initial values, it is obvious that there is a noticeable decrease at short-circuit current and $I_{\mathrm{mp}}$. Also, total efficiency presents a steady decrease during temperature degradation.

Finally, device 3 finger 4 was used for the air and $\mathrm{O}_{2}$ plasma degradation testing. At first, the device was exposed to air for 8 minutes, and after that, 6 minutes of $\mathrm{O}_{2}$ plasma degradation occurred. A power loss of 13,3\% occurred after 8 minutes of air degradation, while after the 6-minute $\mathrm{O}_{2}$ plasma degradation, maximum output power decreased by a further $4,3 \%$ (Table 8 ).

From the analysis, it is apparent that annealing, air, gaseous oxygen, and oxygen plasma degradation have similar effects with PID, while due to simple diode characteristics, organic cells proved to be relatively durable to potential induced degradation. At low voltages $(10 \mathrm{~V})$, the organic cells withstood degradation adequately, with a drop of $23 \%$ in their initial efficiency. As voltage increased, the degradation rate increased considerably reaching a 93\% efficiency drop when $30 \mathrm{~V}$ was applied for 20 minutes.

\section{Conclusions}

From the experimental measurements carried out in the five devices, it is apparent that organic solar cells are physically voltage durable, meaning that they do not show macroscale degradation at their appearance even after application of a $30 \mathrm{~V}$ voltage. In all cases examined, after voltage degradation, 
the organic cell's quantum efficiency lambda curve moved to I-V charts' $x$-axis as a result of lower current generation. In other words, after degradation, a smaller EQE is observed at almost the same wavelengths. Moreover, similar degradation effects are also experienced in their I-V characteristics. The potential induced degradation is evident as there is a distortion in the cells' diode characteristic, and therefore, their I-V curves have straightened.

Furthermore, it was noticed that organic cells were vulnerable to degradation due to ambient conditions such as air, oxygen, and high temperature. Under small voltage applications such as $10 \mathrm{~V}$, organic cells started to charge due to their capacitive features, and as a result, total efficiency increased. This increase was only temporary, as efficiency started to decrease without any other external degradation after cell discharging via an anode-cathode short circuiting.

As there are no many studies regarding this phenomenon, this study enlightens PID phenomena in organic cells and shows its limits. The results of the study offer an initial step for better understanding the degradation effects, giving manufacturers ideas in order to focus on solving these problems and make organic photovoltaic cells more feasible for the market.

\section{Conflicts of Interest}

The authors declare that there is no conflict of interest regarding the publication of this paper.

\section{References}

[1] M. Rekinger, F. Thies, G. Masson, and S. Orlandi, Global Market Outlook for Solar Power 2015-2019, SolarPower, Europe, 2015.

[2] A. Gambhir, P. Sandwell, and J. Nelson, "The future costs of OPV-A bottom-up model of material and manufacturing costs with uncertainty analysis," Solar Energy Materials and Solar Cells, vol. 156, pp. 49-58, 2016.

[3] W. F. F. Mohamed, Voltage and Time Dependence of the Potential Induced Degradation Effect for Different Types of Solar Modules, [M.S. Thesis], Kassel University, Germany, 2014.

[4] P. Hacke, R. Smith, K. Terwilliger et al., "Testing and analysis for lifetime prediction of crystalline silicon PV modules undergoing degradation by system voltage stress," IEEE Journal of Photovoltaics, vol. 3, no. 1, pp. 246-253, 2013.

[5] G. Tamizh Mani, Crystalline Silicon Terrestrial Photovoltaic Cells-Supply Chain Procurement Specification Guideline, Solar America Board for Codes and Standards, Arizona State University, Photovoltaic Reliability Laboratory, Arizona, USA, 2015.

[6] S. Sakamoto, T. Kobayashi, and S. Nonomura, "Epidemiological analysis of degradation in silicon photovoltaic modules," Japanese Journal of Applied Physics, vol. 51, no. 10S, article 10NF03, 2012.

[7] J. A. Del Cueto and T. J. McMahon, "Analysis of leakage currents in photovoltaic modules under high-voltage bias in the field," Progress in Photovoltaics: Research and Applications, vol. 10, no. 1, pp. 15-28, 2002.

[8] P. Hacke, K. Terwilliger, S. Glick et al., "Interlaboratory study to determine repeatability of the damp-heat test method for potential-induced degradation and polarization in crystalline silicon photovoltaic modules," IEEE Journal of Photovoltaics, vol. 5, no. 1, pp. 94-101, 2015.

[9] J. Berghold, O. Frank, and H. HoehneS. Pingel, B. Richardson, and M. Winkler, "Potential induced degradation of solar cells and panels," in Proceeding 25th EUPVSEC, pp. 3753-3759, Valencia, Spain, 2010.

[10] P. Hacke, K. Terwilliger, R. Smith et al., "System voltage potential-induced degradation mechanisms in PV modules and methods for test," in 2011 37th IEEE Photovoltaic Specialists Conference, pp. 000814-000820, Seattle, WA, 2011.

[11] J. A. Del Cueto and S. R. Rummel, "Degradation of photovoltaic modules under high voltage stress in the field," in SPIE Solar Energy+ Technology, International Society for Optics and Photonics, San Diego, California, 2010.

[12] S. Akcaoğlu, Voltage and Time Dependence of the Potential Induced Degradation Effect for Organic, Perovskite and DyeSensitized Solar Cells, [M.S. Thesis], International Hellenic University, Greece, 2016. 

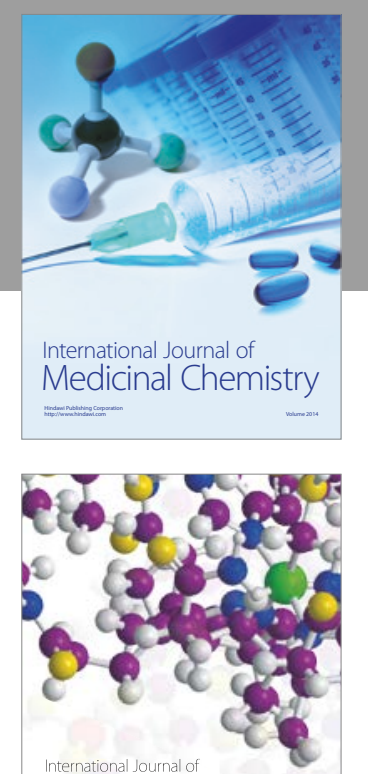

Carbohydrate Chemistry

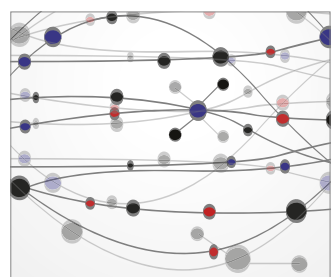

The Scientific World Journal
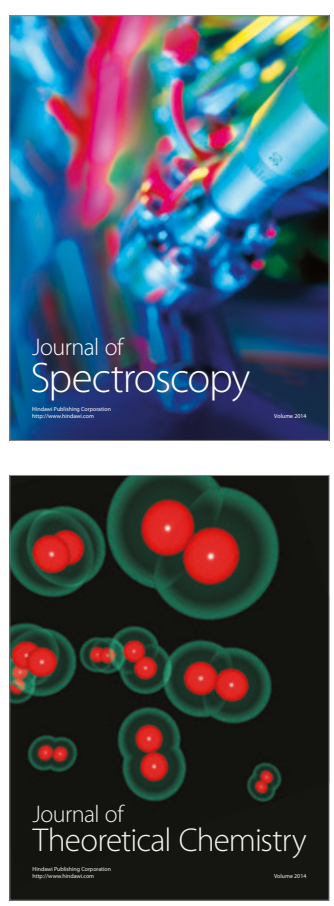
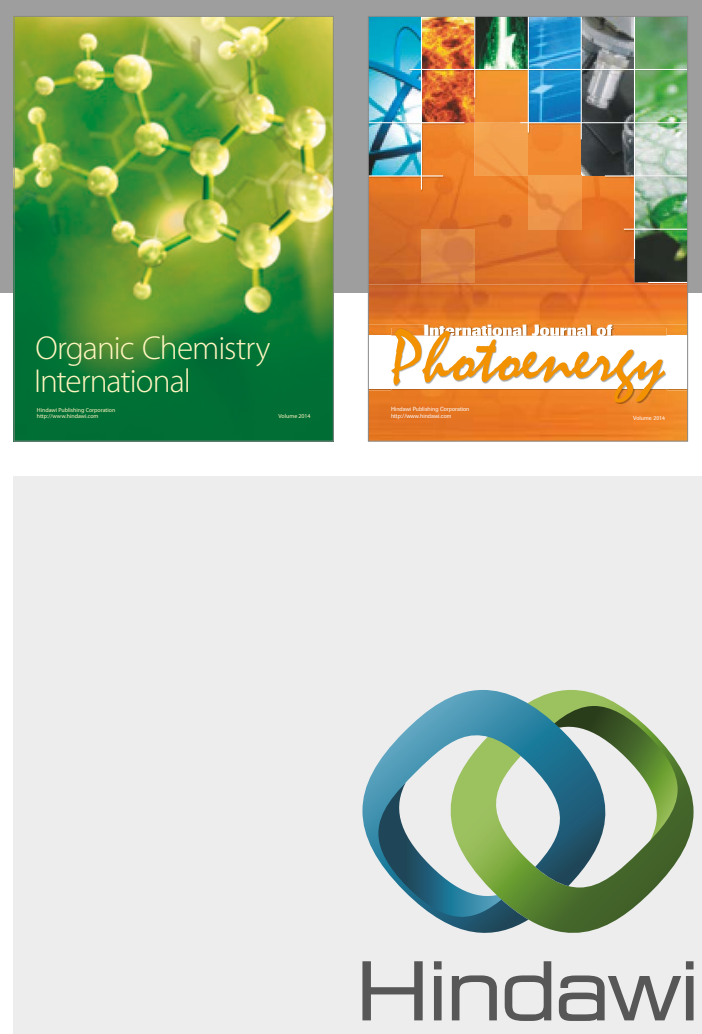

Submit your manuscripts at

https://www.hindawi.com

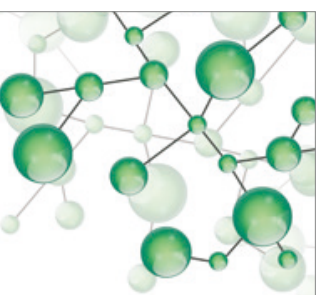

International Journal of

Inorganic Chemistry

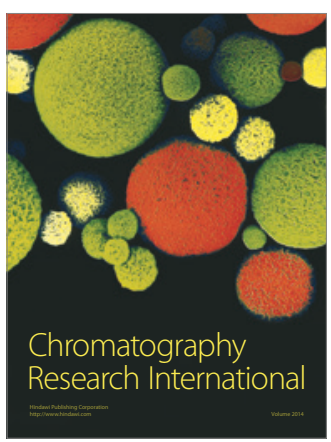

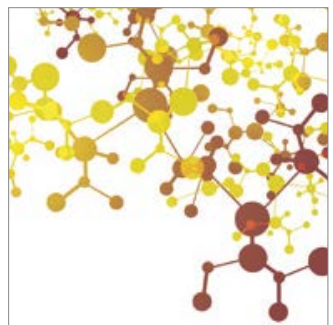

Applied Chemistry
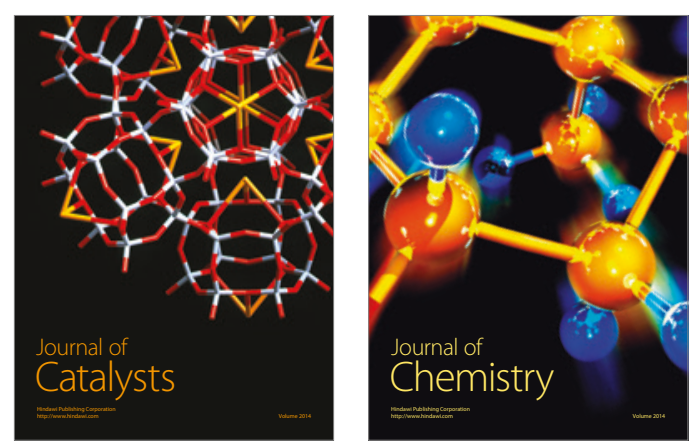
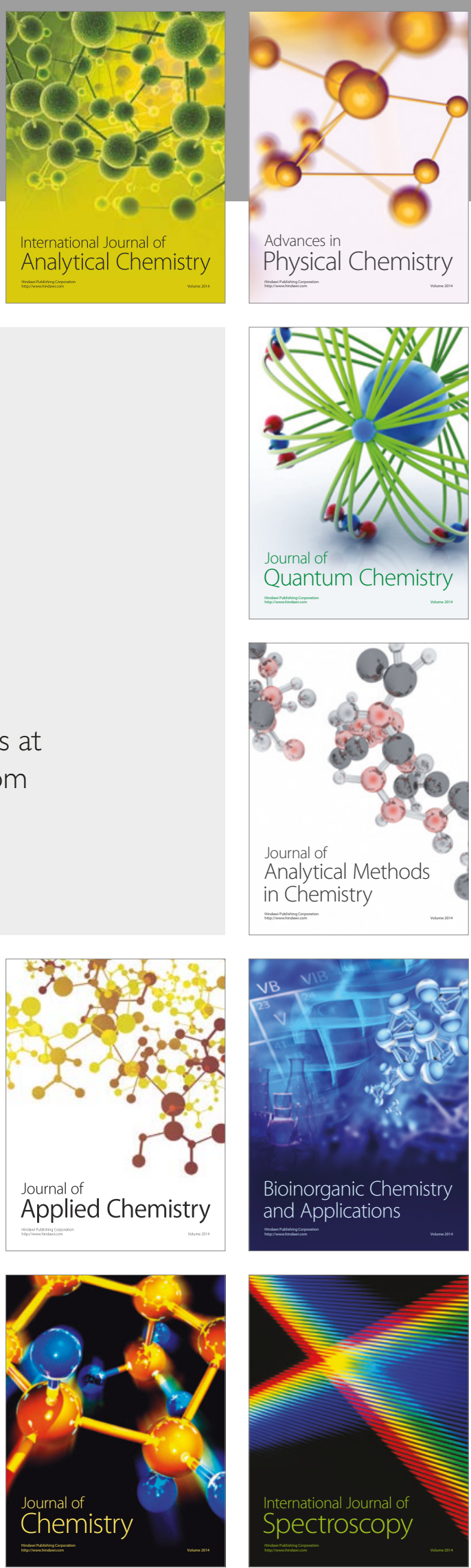